(с) Колектив авторів, 2016

УДК 616.24-002:616.831-002:355.11

DOI

\author{
В.І. Трихліб, А.Б. Щур, М.О. Павловська, Г.А. Музика, С.І. Ткачук, О.Л. Панасюк
}

\title{
ПНЕВМОНІЯ ТА ЕНЦЕФАЛІТ ЯК УСКЛАДНЕННЯ ГОСТРИХ РЕСПІРАТОРНИХ ЗАХВОРЮВАНЬ І ГРИПУ
}

\begin{abstract}
Українська військово-медична академія, Центральний військово-медичний клінічний центр Центрального Регіону, Центральний військово-медичний клінічний центр Південного Регіону, Центральний військовомедичний клінічний центр Західного Регіону, Інститут епідеміології та інфекційних хвороб ім. Л.В. Громашевського НАМН України
\end{abstract}

Наводиться огляд літератури стосовно ускладнення грипу та гострих респіраторних захворювань пневмонією, енцефалітом та можливі їх збудники. Приведено опис випадку розвитку пневмонії та енцефраліту у військовослужбовця на фроні гострого респіраторного захворювання.

Ключові слова: пневмонія, енцефраліт, військовослужбовці.

Гострі респіраторні захворювання (ГРЗ) та грип залишаються актуальними як серед цивільного населення, так і серед військовослужбовців вже протягом багатьох десятиліть. Під час епідемічних підйомів захворювань відсоток захворілих на ГР3 та грип може досягати 3640 \% від зареєстрованих випадків за рік. При звичайних епідемічних спалахах ГРЗ та грипу хворіє близько $10 \%$ населення.

Якщо брати до уваги етіологічну структуру ГР3, то існує велика кількість як вірусів (більше 200), так і бактерій, які викликають ці захворювання. Провідну етіологічну роль відіграють віруси грипу А, B, C, парагрипу 1, 2 та 3 типів, респіраторно-синцитіальний, адено-, пікорна-, коронавіруси та ін.

При цих захворюваннях реєструються різноманітні ускладнення з ураженням різних органів, які, як правило, обумовлені приєднанням вторинної бактерійної інфекції, але в той же час можуть бути обумовлені і самими вірусами. Серед ускладнень можуть розвинутись такі: синусит, пневмонія, міокардит, ларингіт, реактивний (токсичний) гепатит, ITШ, бронхіт, менінгізм, інфрекційнотоксична енцефалопатія, енцефраліт та ін.

3 урахуванням того, що під час АТО серед військовослужбовців реєструвались випадки ГРЗ, які в подальшому ускладнювались пневмонією та енцефалітом, метою нашої роботи було здійснити огляд літератури стосовно можливих збудників, які можуть викликати ці ускладнення, та описати деякі випадки для розуміння лікарів.

\section{Матеріали і методи}

Було здійснено огляд літератури згідно з поставленою метою дослідження та вибірку даних з історій хвороб військовослужбовців, які лікувались в інфекційних відділеннях госпіталів з приводу ГРЗ, перебіг яких ускладнився пневмонією та енцефралітом.

\section{Результати досліджень та їх обговорення}

Неврологічні ускладнення при грипі давно відомі. Ураження ЦНС при грипі реєструються рідко. Ці ускладнення при сезонному грипі серед дітей та молодих людей були описані рядом авторів [1-3]. Як правило, ураження нервової системи асоціюється 3 грипом А. Описані випадки неврологічних ускладнень у вигляді енцефаліту під час минулої пандемії грипу 2009 у дітей $[1,2,4,5]$. Рядом авторів було описано розвиток енцефалопатії, енцефаліту і у дорослих хворих з новим H1N1 грипом [6, 7].

Опис розвитку епілептиформних нападів, енцесраліту, мієліту, судом, синдрому Рея, синдрому Гійєна-Барре, інших неврологічних розладів на фроні ураження органів дихання при сезонних захворюваннях на грип A та B наводяться рядом авторів $[1,2,8]$. Про велику частку ускладнень на фроні грипу у дітей з розвитком енцефаліту, синдрому Рея, гострої некротизуючої енцефралопатії, мієліту, автоімунних захворювань типу синдрому Гійєна-Барре під час епідемій грипу повідомляється в Японії [9].

Також є інорормація про можливість розвитку енцефраліту, енцесралопатії і при грипі В [10].

Перебіг захворювань спостерігався від легкого до тяжкого, навіть 3 летальними наслідками. Як правило, неврологічні ускладнення розвиваються в період розпалу захворювання $[11,12]$. Так, Delorme L. зі співавт. (1979 р.) описують випадок у дорослої людини з ускладненням через 5 діб після захворювання легень, розвитком пневмонії [12]. В цьому випадку у хворого була втрата свідомості з в'ялою квадриплегією та з поширеним ура- 
женням головного мозку. Хворому проводилась терапія із застосуванням озельтамівіру та метилпреднізолону внутрішньовенно. Хворий одужав.

Випадок грипу А 3 енцефралітом у тяжкій фрормі 3 розвитком летального наслідку описували Incecik F. зі співавт. [13]. А про легкий перебіг навіть у хворих на грип H1N1 з неврологічними ускладненнями описували інші автори [4].

При енцефалітах, за даними одних дослідників, вірусна РНК неодноразово виявлялась за допомогою методу ПлР у спинномозковій рідині [14]. В той же час іншими дослідниками вірусну РНК у багатьох хворих на грип з розвинутим енцефалітом у спинномозковій рідині не знаходили [15]. Внаслідок чого була висунута гіпотеза про сумнівність прямого вірусного впливу на розвиток цього ускладнення. Більш вірогідна роль у розвитку запального процесу цитокінів, які утворювались на фоні ураження органів дихання.

Описано тяжкий випадок 3 поширеним ураженням легень, м'язів, головного мозку на фроні пандемічного грипу H1N1 [16].

Під час епідемії в Бангкоку, Таїланді, протягом року з 1 червня 2009 р. по 31 травня 2010 р. пневмонія була найбільш частим ускладненням захворювання на пандемічний грип (в 43,2 \% випадків). Також спостерігали й інші ускладнення: бронхіоліт, кровохаркання, гострий респіраторний дистрес-синдром та енцефаліт [17].

Ураження легень та центральної нервової системи спостерігається при ВІЛ-інфекції при генералізованому пневмоцистозі. Так, випадок швидко прогресуючого генералізованого пневмоцистозу у хворого з IV стадією ВІЛ-інсрекції, який не отримував антиретровірусну терапію, був описаний $Є$.І. Красновою [18]. У цьому випадку генералізований пневмоцистоз розвинувся на фоні дисемінованого кандидозу 3 розвитком менінгоенцефаліту. Пневмоцистоз був діагностований вже тільки посмертно при гістологічному дослідженні, коли були виявлені вогнища із пневмоцист у печінці, нирках, селезінці, лімфатичних вузлах біфуркації трахеї, легень, м'якій мозковій оболонці та головному мозку.

За даними деяких авторів, у структурі серозних менінгітів 22 \% випадків були хламідійної етіології, а в структурі менінгоенцесралітів - у 9 \% даної етіології. В групі хламідійних менінгітів та менінгоенцефалітів частка C. trachomatis склала $32 \%$, C. pneumonia - $28 \%$, C. psittaci - 40 \%. В інших випадках захворювання були спричинені мікст-інфрекцією, і в деяких випадках хлімідійна інорекція не виявлялась. В структурі мікстінфекції часто спостерігаються ентеровіруси. При гнійних менінгітах хламідійна інфекція часто асоціювала 3 менінгококом [19].
У молодих осіб також описують випадки розвитку енцефраліту, викликаного мікоплазмою пневмонії. Показано, що ускладнення з боку ЦНС можуть розвинутись навіть при легкій фрормі мікоплазменої інфекції з ураженням легень. Причому рентгенологічні прояви ураження можуть імітувати крововилив або абсцес [20].

Можливість ураження ЦНС метапневмовірусом 3 розвитком енцефаліту у дітей описують ряд авторів [2123]. В одному випадку метапневмовірус був знайдений на автопсії як в тканині мозку, так і в легенях [24]. В той же час описують розвиток енцефаліту в зимові місяці у дорослого в Австралії у 2014 р. У чоловіка (47 років) на другу добу захворювання на фроні симптомів ураження органів дихання (були кашель, задишка, риніт, міалгії, біль голови) розвинувся енцефраліт з втратою свідомості. Хворий був обстежений на мікоплазму пневмонії, віруси простого герпесу, вітряної віспи, ентеровірус, цитомегаловірус, вірус Епштейна-Барр, паранеопластичні антитіла - отримані негативні результати. 3 урахуванням відсутності позитивного результату на фроні лікування антибактерійними препаратами, ацикловіром, хворому було проведено 5-денний курс терапії внутрішньовенно 1 г метилпреднізолону. В подальшому виявлено метапневмовірус. Авторами висловлено думку про необхідність обстеження на метапневмовірус хворих з енцефралітом, у яких була попередня респіраторна інфекція, не тільки дітей, а також і дорослих [25].

Далі описуємо випадок захворювання військовослужбовця під час АTO, який надійшов на лікування 3 приводу захворювання органів системи дихання та в якого в подальшому розвинувся енцефаліт.

Хворий, молодший сержант Г.С.А., 1972 р.н., призваний 03.2015 р. з м. Києва, надійшов у інфрекційне відділення гарнізонного госпіталю 25.03.15 р. зі скаргами на загальну слабкість, кашель, біль у грудній клітці, озноб, підвищення температури до фребрильних цифр. Захворів 23.03.15 р., коли підвищилася температура, виникли кашель, загальна слабкість. У МП частини лікувався з приводу гострого бронхіту, отримував тілорон, ремантадин, бромгексин, жарознижуючі. ФЛГ від 24.03 - норма.

25.03.15 р. у зв'язку з відсутністю ефекту був направлений до інфрекційного відділення госпіталю. При надходженні у відділення госпіталю температура тіла фребрильна, свідомість ясна, слизова ротоглотки гіперемована, шкірний покрив чистий, лімфовузли не збільшені, АТ 110/40 мм рт. ст., пульс 96 уд./хв, ЧД - 18 за хв. В легенях дихання жорстке, хрипів немає. ЗАК від 26.03.15p.: Нb 140 г/л, ер. 4,4×1012/л, лейк. 4,9×109/л, ШOE 8 мм/год, п/я 5 \%, с. 65 \%, м. 2 \%, лімqр. $25 \%$, баз. $3 \%$. Загальний аналіз сечі в нормі. Отримував лікування: парацетамол, амізон - по 0,5 г 3 р. на добу, амброк- 
сол, цефртріаксон - по 1,0 г 2 р. на добу, диклофренак при підвищеній температурі, інфрузійно-дезінтоксикаційну терапію до 600-1000 мл на добу.

28.03 стан хворого погіршився, приєдналася неадекватність поведінки, змінився рівень свідомості, хворий був дезорієнтований у власній особистості, не орієнтувався в просторі, часі, на питання відповідав не по суті. Очні щілини $D=S$, зіниці $D>S$, фротореакції дещо пригнічені, обличчя симетричне, сухожильні рефрлекси S>D, пожвавлені зліва, гіперестезія на нижніх кінцівках. Позитивний симптом Маринеску-Радовічі, патологічних ступних та менінгеальних ознак не визначалося. Ністагм обох очей, ангіопатія судин сітківки обох очей. ЗАК від 28.03.15 р.: Нb 144 г/л; ер. 4,5×1012/л, лейк. 8,4×10\%/л; КП - 0,9, п/я $17 \%$, с. $56 \%$, м. $1 \%$, лімф. $25 \%$, е. $1 \%$, ШОЕ 15 мм/год. ЕКГ: ритм синусовий, правильний. ЧСС - 88 за хв, повна блокада правої ніжки пучка Гіса. 28.03.15: інфрільтрація легеневої тканини в $S_{3}, S_{4}, S_{5}$ (середньої інтенсивності), зліва в $S_{1}, S_{2}, S_{3}$ (гомогенне затемнення) Легеневий малюнок в $S_{4}, S_{5}$ посилений. Корні легень інфрільтровані. Синуси вільні, куполи діафрагми ущільнені.

З урахуванням негативної динаміки у стані хворого, 28.03.15 р. він з діагнозом направлення «Гостре респіраторне захворювання, тяжкий перебіг, ускладнений вірусним енцефралітом» був переведений до центрального госпіталю регіону. При надходженні на наступний лікувальний госпітальний етап хворий дезорієнтований в часі та просторі. На правому крилі носа висипка, схожа на герпетичну. Гіперемія м'якого піднебіння, лімфовузли не збільшені. Пульс 84 в хв, АT 105/60 мм рт. ст., ЧД 18 за хв. При аускультації: послаблення дихання над всією легенею зліва, справа - жорстке, по передній поверхні грудної клітки та пахвовим лініям - вологі дрібнопухирчасті хрипи, перкуторно - притуплення легеневого звуку зліва. Живіт безболісний. Нижній край печінки не пальпується. Селезінка не збільшена. Рухи в суглобах у повному обсязі, сила м'язів та тонус не змінені. Сухожильні рефрлекси симетричні, патологічних рефрлексів немає. Гіперестезія нижніх кінцівок. Позитивний рефрлекс Бехтерева. Діагноз: ГРВІ, тяжкий перебіг. Негоспітальна двобічна полісегментарна пневмонія верхньої долі $\left(\mathrm{S}_{1}\right.$, $\left.S_{2}, S_{3}\right)$ лівої легені та верхньої частки $\left(S_{3}, S_{4}, S_{5}\right)$ правої легені, тяжкий перебіг, IV клінічна група, ДН II cm. Гострий вірусний менінгоенцефраліт, тяжкий перебіг. Призначено: меропенем 1,0 г 3 р. на добу, амікацин 1,0 г, таміфрлю 0,75×2 р. на добу, ацикловір 500 мг 3 р. на добу, Біовен-моно 50 мл 1 р. на добу.

29.03.15 р. стан хворого залишався тяжким. Хворий в свідомості, доступний до продуктивного мовного контакту, має скарги на загальну слабкість, малопродуктивний кашель. Дихання жорстке, послаблене в нижньобазальних відділах, поодинокі сухі хрипи. АТ 95/65 мм рт. ст. Пульс 88 уд. за хв. ЧД 20 за хв. Сатурація 89-90\%.

30.03.15 р. зберігається продуктивний кашель, загальна слабкість. Температура тіла в межах норми. Свідомість ясна, повністю доступний до контакту, на запитання відповідає чітко, розгорнуто. Над легенями везикулярне дихання, послаблене над верхньою долею лівої легені, вислуховуються вологі дрібнопухирчасті хрипи і в правій пахвовій ділянці з крепітацією. Проведено рентгенографрію: слабкопозитивна інфільтрація справа в $S_{3}, S_{4}, S_{5}$, зліва в $S_{1}, S_{2}, S_{3}$ І Інтенсивність та розміри інфрільтрації зменшились. Ліквор без кольору, прозорий; білок 0,33 г/л; реакція Панді слабо позитивна; реакція Нонне-Апельта негативна; цитоз - 1 кл./мкл; мікроскопія: лейк. 0-0-1 в препар., еритр. - 0-1 в препар., глюкоза - 3,5 ммоль/л, хлориди - 105 ммоль/л.

31.03.15 р. стан середньої тяжкості. Скарг активно не висловлює. Свідомість ясна. Зберігається гіперемія слизової ротоглотки. Дещо утруднене носове дихання. Зберігаються зліва по передній поверхні над верхньою долею поодинокі вологі хрипи, в правій пахвовій ділянці дещо ослаблене везикулярне дихання, хрипів немає. Менінгеальні знаки відсутні. Ан. крові від 31.03: лейк. 7,7×10\%/л., Нb 145 г/л, ер. 4,58×1012/л, тромбоцити 292×10\%/л, КП - 0,9, п/я $27 \%$, с. $53 \%$, лімфр. $16 \%$, м. $2 \%$, еоз. $2 \%$, ШОЕ 43 мм/год. Протромбіновий індекс 77 \%, фрібриноген плазми 7,54, фрібриноген В 3+. Біохімічний аналіз крові: АсАТ 78 од./л, АлАТ 117 од./л, загальний білірубін 8,0 мкмоль/л, креатинін 98 мкмоль/л, сечовина 4,9 ммоль/л, глюкоза 5,7 ммоль/л, загальний білок 59 г/л.

02.04.15 р. турбує періодичне покашлювання. Загальний стан задовільний. Свідомість ясна. Дихання ослаблене над верхньою часткою лівої легені, де вислуховуються вологі дрібнопухирчасті хрипи, справа в пахвовій ділянці крепітація. АТ 105/70 мм рт.ст. Гемодинамічні показники стабільні, задовільних якостей. За даними рентгенографрії, незначна позитивна динаміка. У зв'язку з протеїн- і лейкоцитурією виконано дообстеження: сеча за Нечипоренко, проба Зимницького, добова протеїнурія. На контрольній рентгенограмі ОГП-незначна позитивна динаміка (справа в $S_{3}, S_{4}, S_{5}$, зліва в $S_{1}, S_{2}, S_{3}$ зберігаються вогнища, але розміри їх зменшились). Аналіз крові від 02.04: лейк. 9,3×10\%/л, Нb 140 г/л, ер. 4,27×1012/л, КП 0,9, п/я 8 \%, с. 68 \%, лімqр. $15 \%$, мон. $6 \%$, еоз. $3 \%$, ШОЕ 38 мм/год. Біохімічний аналіз крові: АсАТ 85 од./л, АлАТ 80 од./л, креатинін 81 мкмоль/л, сечовина 4,3 ммоль/л, загальний білок 58 г/л. Протромбіновий індекс 80 \%, фрібриноген плазми 6,66 2, фрібриноген В 2+. Сеча - світло-жовта, прозора, 
питома вага 1005, кисла, білок 0,066 г/л, глюкоза - не знайдено. Аналіз крові на ВІЛ: методом ІФА антитіла не виявлено.

5.04.15 р. свідомість ясна. ЧМН без особливостей, незначна асиметрія носо-губних зморшок. Рефрлекси з рук і ніг без суттєвої різниці сторін. Патологічні рефрлекси не викликаються, координаційні проби виконує чітко. Тремтіння заплющених повік і витягнутих пальців рук. Дистальний гіпергідроз. Зберігається жорстке дихання, в базальних відділах з обох сторін поодинокі дрібнопухирчасті хрипи, які зникають при покашлюванні. ЗАК: лейк. 6,4×10\%/л, ШОЕ 45 мм/год. Аналізи крові на ДНК вірусів Епитейна-Барр, цитомегаловірусу, звичайного герпесу I та II - негативні. Подальшу терапію продовжено чефепімом по 1,0 г в/в струминно 2 р. на добу, аброл -по 0,75 г 1 m. на добу.

В подальшому стан хворого покращувався. Зменшився кашель, нормалізувалась температура тіла. За даними рентгенографії ОГП від 9.04.15 р., інфрільтрація $\mathrm{S}_{5}$ справа з інфрільтрацією міжчасткової плеври, інфрільтрація $S_{3}$ зліва, посилений легеневий малюнок, синуси вільні. Двобічна полісегментарна пневмонія справа - $S_{3}$, $S_{4}, S_{5}$, зліва в $S_{1}, S_{2}, S_{3}$ Аналіз крові від 10.04.15 р.: лейк.

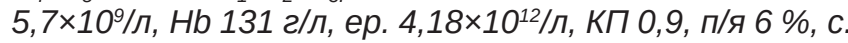
$48 \%$, лімф. $41 \%$ мон. 4 \%, еоз. $1 \%$, ШОЕ 25 мм/год.

З 20.04. стан розцінювався як задовільний. Температура тіла стійко нормалізувалась. Над легенями везикулярне дихання, хрипи не вислуховувались. На рентгенограмі від 17.04.15 р. позитивна динаміка, інфільтрація справа в $\mathrm{S}_{3}$ розсмокталась, в $\mathrm{S}_{4}$ ma $\mathrm{S}_{5}$ зменшилася в розмірах та інтенсивності. Зліва в $S_{3}$ малюнок фріброзно змінений. В загальному аналізі крові: лейк. 5,7×10\%/л, ШОЕ 25 мм/год.

Виписаний 29.04.2015 р. $з$ діагнозом: «Негоспітальна двобічна полісегментарна пневмонія тяжкого перебігу, ускладнена легеневою недостатністю II, з фрормуванням обмеженого плевропневмофіброзу в середній частці правої легені та верхній частці лівої легені $\left(\mathrm{S}_{3}\right)$, гострим вірусним менінгоенцефралітом, реактивним гепатитом з мінімальним ступенем активності.

\section{Висновок}

У хворих з ГРЗ, грипом, ускладненим пневмонією, порушення свідомості може бути проявом інфекційнотоксичного шоку, розвитку енцефаліту або менінгоенцефаліту. Серед збудників неврологічних ускладнень у хворих з пневмонією можуть бути віруси сезонного грипу, нового пандемічного грипу (H1N1), метапневмовірус, мікоплазма, хламідія, що слід передбачати при проведенні діагностичного пошуку та лікуванні, так як переважно практикуючі лікарі обстежують хворих тільки на герпес-групу.

\section{Література}

1. Neurologic complications associated with influenza $A$ in children during the 2003-2004 influenza season in Houston, Texas / [S.M. Maricich, J.L. Neul, T.E. Lotze et al.] // Pediatrics. - 2004 - Vol. 114. - P. 626-633.

2. Encephalitis and encephalopathy associated with an influenza epidemic in Japan / [T. Morishima, T. Togashi, S. Yokota et al.] // Clin. Infect. Dis. - 2002. - Vol. 35. - P. 512-517.

3. Acute necrotizing encephalopathy in a child with $\mathrm{H} 1 \mathrm{~N} 1$ influenza infection / [J.B. Lyon, C. Remigio, T. Milligan et al.] // Pediatr. Radiol. - 2010. - Vol. 40. - P. 200-205.

4. Centers for Disease Control and Prevention (CDC). Neurologic complications associated with novel influenza $A(\mathrm{H} 1 \mathrm{~N} 1)$ virus infection in children - Dallas, Texas, May 2009 / MMWR. Morb. Mortal. Wkly Rep. - 2009. - Vol. 58. - P. 773-778.

5. Neurological complications of pandemic influenza A H1N1 2009 infection: European case series and review // [P. Surana, S. Tang, M. McDougall et al.] // Eur. J. Pediatr. - 2011. - Vol. 170, N 8. - P. 1007-1015.

6. Gonzalez B.E. Novel influenza A (H1N1) presenting as an acute febrile encephalopathy in a mother and daughter / B.E. Gonzalez, D.G. Brust // Clin. Infect. Dis. - 2009. - Vol. 49. - P. 1966-1967.

7. H1N1 encephalitis with malignant edema and review of neurologic complications from influenza / [P.T. Akins, J.Belko, T.M. Uyeki et al.] // Neurocrit. Care. - 2010. - Vol. 13, N 3. - P. 396-406.

8. Myelitis associated with influenza A virus infection / [O. Salonen, M. Koshkiniemi, A. Saari et al.] // J. Neurovirol. - 1997. - Vol. 3. P. 83-85.

9. Studahl M. Influenza virus and CNS manifestations / M. Studahl / J. Clin. Virol. - 2003. - Vol. 28, N 3. - P. 225-232.

10. Influenza B virus encephalitis / J.A. McCullers, S. Facchini, P.J. Chesney, R.G. Webster // Clin. Infect. Dis. - 1999. - Vol. 28 N 4. - P. 898-900.

11. Hoult J.G. Influenzal encephalopathy and post-influenzal encephalitis; histological and other observations / J.G. Hoult, T.H. Flewett // Br. Med. J. - 1960. - Vol. 1. - P. 1847-1850.

12. Delorme L. Influenza A virus associated with acute encephalopathy / L. Delorme, P.J. Middleton // J. Dis. Child. -1979. - Vol. 133. - P. 822-824.

13. Fatal encephalitis associated with novel influenza $A(H 1 N 1)$ virus infection in a child / [F. Incecik, M. Ozlem Hergüner, S. Altunbasak et al.] // Neurol. Sci. - 2012. - Vol. 33, N 3. - P. 677-679.

14. PCR on cerebrospinal fluid to show influenza-associated acute encephalopathy or encephalitis / [S. Fujimoto, M. Kobayashi, O. Uemura et al.] // Lancet. - 1998. - Vol. 352. - P. 873-875.

15. Influenza RNA not detected in archival brain tissues from acute encephalitis lethargica cases or in postencephalitic Parkinson cases / [S. McCall, J.M. Henry, A.H. Reid et al.] // J. Neuropathol. Exp. Neurol. - 2001. - Vol. 60. - P. 696-704.

16. Adult Patient with Novel H1N1 Infection Presented with Encephalitis, Rhabdomyolysis, Pneumonia and Polyneuropathy $/$ [K.K. Patel, A.K. Patel, Sh. Shah et al.] / J. Glob. Infect. Dis. - 2012. - Vol. 4, N 3. - P. 178-181.

17. Lochindarat S. Clinical presentations of pandemic 2009 influenza A (H1N1) virus infection in hospitalized Thai children / S. Lochindarat, T. Bunnag // J. Med. Assoc. Thai. - 2011. - Vol. 94, N 3. - P. 107-112.

18. Краснова Е.И. Случай быстро прогрессирующего генерализованного пневмоцистоза у больного 4В стадией СПИДа / Е.И. Краснова // Инфекционные болезни: научно-практический журнал Нац. науч. общества инфекционистов. - 2015. - Т. 13, № 2. - C. 71-76. 
19. Поражения нервной системы при хламидийной инфекции / http://xn--90ahmefijp4a.xn--p1ai/page,2,57-porazheniya-nervnoysistemy-pri-hlamidiynoy-infekcii.html

20. Burman L.G. Recurrent Pneumonia and Encephalitis due to Mycoplasma Pneumoniae / L.G. Burman, S. Löfgren // Scand. J. Infect. Dis. - 1979. - Vol. 11, N 2. - P. 170-172

21. Human metapneumovirus associated with central nervous system infection in children / [J.C. Arnold, K.K. Singh, E. Milder et al.] / J. Pediatr. Infect. Dis. - 2009. - Vol..28. - P. 1057-1060.

22. Acute encephalopathy associated with human metapneumovirus infection / T. Niizuma, A. Okumura, K. Kinoshita, T. Shimizu // Jpn. J. Infect. Dis. - 2014. - Vol. 67. - P. 213-215.

23. Human metapneumovirus in the cerebrospinal fluid of a patient with acute encephalitis / [F.I. Sánchez, P.M. Rebollo, A..C Muñoz et al.] // Arch. Neurol. - 2012. - Vol. 69. - P. 649-652.

24. Human metapneumovirus RNA in encephalitis patient / [O. Schildgen, T. Glatzel, T. Geikowski et al.] // Emerg. Infect. Dis. 2005. - Vol. 11. - P. 467-470.

25. Encephalitis-Associated Human Metapneumovirus Pneumonia in Adult, Australia / [A. Fok, C. Mateevici, B. Lin et al.] / [Електроний ресурс]. - Режим доступу: http://wwwnc.cdc.gov/eid. - Назва 3 екрану.

\section{PNEUMONIA AND ENCEPHALITIS AS COMPLICATIONS OF ACUTE RESPIRATORY INFECTIONS AND INFLUENZA}

V.I. Trykhlib, A.B. Shchur, M.O. Pavlovska, H.A. Muzyka, S.I. Tkachuk, O.L. Panasiuk

SUMMARY. The article provides a review of the literature on complications of influenza and acute respiratory infections with pneumonia, encephalitis and their possible agents. The description of cases of pneumonia and encephalitis in the soldier on a background of acute respiratory disease is illustrated.

Key words: pneumonia, encephalitis, military.

Отримано 24.02.2016 р.

\title{
М.Д. Чемич, В.В. Ільїна, М.В. Лимарь \\ КЛІНІКО-ЕПІДЕМІОЛОГІЧНІ ОСОБЛИВОСТІ ГЕРПЕСВІРУСНОЇ ІНФЕКЦІї
}

\author{
Сумський державний університет
}

Проаналізовано клінічні особливості герпесвірусних інфекцій (ГВІ). Встановлено, що на ГВІ частіше хворіють жінки старше 40 років. Причиною первинної форми недуги є контакт з хворою людиною, реактивація інфекції відбувається внаслідок переохолодження, ГРВІ, нервово-емоційних стресів. 3 клінічних фрорм переважає хронічна (реактивована). У хворих на VZV частіше діагностується спінальна фрорма з локалізацією процесу за ходом міжреберних нервів. Ускладнення більш характерні для ГВI, спричиненої HSV-1.

Ключові слова: герпесвірусні інфрекції, клінічні особливості.

ГВІ належать до найбільш поширених вірусних хвороб у світі. За даними ВООЗ, близько 80-90 \% населення земної кулі інфіковані одним або декількома типами вірусу герпесу [1]. За сучасною оцінкою, щорічно число уражених зростає на $10 \%$, а смертність, обумовлена ГВІ, займає друге місце після грипу [2]. У хворих
3 онкопатологією ця недуга зустрічається у 50 \%, а при ВІЛ-інфрекції - у 75-90 \% випадків [1, 3].

Збудники ГВІ мають цілу низку властивостей, що зумовлюють особливості клінічного перебігу: розповсюдженість і загальна сприйнятливість, пантропізм, здатність поширюватися в популяції, використовуючи різноманітні механізми передавання, схильність до тривалої персистенції в організмі та реактивації, опортуністичні властивості, імуносупресивна дія, здатність до фрормування органних уражень [4, 5].

ГВІ досить часто перебігають приховано, супроводжуються невираженою клінічною картиною, що є причиною лікарських помилок. Завдяки імуносупресивній дії герпесвірусів, відбувається збій імунної системи зараженого організму, тому інфекції поступово набувають хронічного перебігу з розвитком тяжких органних уражень. Інфікування організму герпесвірусами не супроводжується фрормуванням ефективної імунної пам'яті [6]. Внаслідок виникнення імунодефіцитного ста- 